\title{
Antibacterial Activities of Azadirachta indica and Syzigium guinensee on Bacteria Associated with Urinary Schistosomiasis
}

\author{
Dada, E. O. and Alagha, B. A.* \\ Department of Microbiology, Federal University of Technology Akure, P.M.B 704 Akure, 340001, Nigeria \\ *Corresponding Author
}

\begin{abstract}
:
Background: Bacteria infection of the urinary tract, also known as "Urinary tract infections (UTIs)" are among the most common bacterial infections of humans. Uncomplicated urinary tract infections can be easily treated with antibiotics; however, there is a growing resistance to conventional antibiotics. This has also been reported among bacteria associated in co-infection of urinary schistosomiasis and bacteriuria.
\end{abstract}

Objective: To assess the antibacterial efficacy of aqueous and ethanol extracts of Azadirachta indica and Syzygium guineense leaves against bacteria associated with urinary schistosomiasis.

Methods: Fresh leaves of $A$. indica and $S$. guineense were air dried and extracted using sterile distilled water and ethanol. Phytochemical constituents of $A$. indica and $S$. guineense leaves were elucidated using standard techniques. Antibacterial assay, minimum inhibitory concentration (MIC) and minimum bactericidal concentration (MBC) of the plant extracts against; bacteria isolated from urine samples with single infection of bacteriuria, bacteria isolated from urine samples with coinfection of urinary schistosomiasis and bacteriuria, and typed bacteria were also determined using standard methods.

Results: Qualitatively, saponin, tannin, flavonoid, steroid, terpenoid and glycoside were present in all the plant extracts, while alkaloid and phlobatannin were absent in the extracts. Quantitatively, terpenoid was the highest bioactive compound in aqueous extract of $A$. indica $(25.15 \pm 0.04)$ and ethanol extract of $S$. guineense $(51.16 \pm 0.03)$, while saponin was the highest in the aqueous extract of $S$. guineense $(72.09 \pm 1.67)$ and ethanol extract of $A$. indica $(220.82 \pm 0.64)$. The MIC of the various plant extracts against all the isolates and typed bacteria ranged from $6.25 \mathrm{mg} / \mathrm{mL}-12.5 \mathrm{mg} / \mathrm{mL}$, while the MBC ranged from 6.25 $\mathrm{mg} / \mathrm{mL}-25 \mathrm{mg} / \mathrm{mL}$.

Conclusion: This study revealed the antibacterial candidature of $A$. indica and S. guineense on Gram positive and Gram-negative bacteria isolated from urine.

Keywords: Urinary tract infection, Asymptomatic Bacteriuria, Co-infection, Azadirachta indica, Syzigium guineense.

\section{INTRODUCTION}

$\mathrm{T}$ he vicious cycle of antibiotic resistance even in uncomplicated urinary tract infection remains a public health concern and has motivated researchers to explore the antimicrobial properties of medicinal plants in the treatment of bacterial infection of the urinary tract (Daswani 2019;
Kidane et al., 2019). According to Mahomoodally (2013), medicinal plants remain the classical alternative to antibiotics in the advent of antimicrobial resistance, because, unlike pharmacological drugs, they typically contain mixtures of different phytochemicals, working together catalytically and synergistically to produce a combined effect that surpasses the total activity of the individual constituents. This is credible because medicinal plants have been used since time memorial to cure and alleviate both infectious and non-infectious diseases. Moreover, available reports illustrate that extracts (aqueous/organic) from different parts of medicinal plants and/or their secondary metabolites have been employed for the treatment and/or prevention of urinary tract infections (Shaeen et al., 2019).

According to Shaheen et al. (2019), herbal medicines are effective to combat bacterial resistance with high efficacy, and are easily available with minimal or no side effects. Azadirachta indica and Syzigium spp are notable medicinal plants reported to have therapeutic potentials in the management and cure of urinary tract infections (Itelima et al., 2016 and Abera et al., 2018). These plants have traditional records of treating bacterial and viral infections, and were reported to possess strong antibacterial potency on antibiotic resistant strains, demonstrating a robust potential of treating infections arising from multidrug resistant bacterial strains (Saheen et al.,2019; Tripathi and Singh 2020).

The study of Dada and Benita (2021), reported a higher antibiotic resistance in bacteria isolated in co-infection of urinary schistosomiasis and bacteriuria compared to bacteria isolated from single infection of bacteriuria. However, there are no records of the antibacterial activities of plant extracts on bacteriuria in the study area. Hence, this study examined the antibacterial potency of $A$. indica and $S$. guineense on bacteria associated with urinary schistosomiasis.

\section{METHODOLOGY}

\subsection{Collection of plant Materials}

Fresh leaves of $A$. indica and S. guineense where sourced from farmlands in Owo, Ondo State and authenticated at the Department of Crop, Soil and Pest Management (CSP) of the Federal University of Technology Akure. The leaves were then washed with distilled water and dried under the shade at 
room temperature for one month after which they were blended to fine powder using a dry blender (Euro Premium. Altima 750 watt). Crude extracts of Aqueous and ethanol extracts of $A$. indica and $S$. guineense were obtained using cold percolation methods described by Asoso et al. (2016).

\subsection{Preparation of Different Concentrations of the Extracts}

Methods of Abegunde et al. (2018), was adopted. Two grams ( $2 \mathrm{~g}$ ) of crude extracts of $A$. indica and $S$. guineense leaves were reconstituted into $20 \mathrm{~mL}$ of $30 \%$ dimethysulphoxide (DMSO) to obtain a stock solution with concentration of $100 \mathrm{mg} / \mathrm{mL}$. Serial dilution was then performed to obtain concentrations of $50 \mathrm{mg} / \mathrm{mL}, 25 \mathrm{mg} / \mathrm{mL}$ and $12.25 \mathrm{mg} / \mathrm{mL}$ and $6.25 \mathrm{mg} / \mathrm{mL}$ of each extracts for the antibacterial assay.

\subsection{Preparation of Standard Inoculum for in-vitro Assay:}

Clinical and typed bacteria were obtained from the study of Dada and Alagha (2021). The isolates were first sub cultured overnight in Nutrient broth and then adjusted to 0.5 McFarland standards by diluting the broth with sterile distilled water to obtain $10^{6} \mathrm{CFU} / \mathrm{ML}$. This served as the standard inoculum for antibacterial assays (Nwankwo and Amaechi 2013).

\subsection{Antibacterial Assay}

Antibacterial activity of ethanol and aqueous extracts of $A$. indica and $S$. guineense leaves against test bacterial isolates and typed strains was carried out using agar-well diffusion method of Abegunde et al. (2018). 18 - 24 hours old broth cultures of the bacterial isolates were standardized to 0.5 McFarland standards $\left(10^{8} \mathrm{cfu} / \mathrm{ml}\right)$ and inoculated on the sterilized solidified Mueller Hinton agar plates using sterilized cotton swabs and allowed to set for 15 minutes. 5 wells of 6 $\mathrm{mm}$ diameter and $3 \mathrm{~mm}$ depth were made in the solidified agar using a sterile borer. About $1 \mathrm{~mL}$ of test samples which are the crude Ethanol extracts of $A$. indica leaves, Aqueous extracts of $A$. indica leaves, Ethanol extracts of $S$. guineense leaves and Aqueous extract of $S$. guineense leaves (100 $\mathrm{mg} / \mathrm{ml}$ ) were aseptically dispensed into the wells, while the fifth well was filled with $1 \mathrm{~mL}$ of distilled water as control and allowed to stand for 15 minutes for pre-diffusion of samples. The plates were allowed to stand upright for 1 hour for proper dilution of the solutions into the medium then incubated at 37 ${ }^{\circ} \mathrm{C}$ for 24 hours. Sensitivity of the test bacteria to the extracts were determined using the radius of inhibition; to obtain this, first the diameters of the zone of inhibition surrounding the wells was first measured with a transparent calibrated ruler in millimetre $(\mathrm{mm})$, and the diameter of the bored well was also calculated. After these, the diameter of the well was subtracted from that of the entire zone of inhibition. The corresponding value was then divided by two to obtain the value of the radius. The effects of the crude plant extracts on bacterial isolates were compared with conventional antibiotics which served as a positive control. All the tests were performed and recorded in triplicates.

\subsection{Determination of Minimum Inhibitory Concentration:}

Determination of the minimum inhibitory concentration (MIC) was carried out using the Broth dilution method of Abegunde et al. (2018). Stock solutions of each plant extracts were prepared by dissolving the powdered extracts in Dimethyl sulfoxide (DMSO). After which concentrations of $100 \mathrm{mg} / \mathrm{ml}, 50 \mathrm{mg} / \mathrm{ml}, 25 \mathrm{mg} / \mathrm{ml}, 12.5 \mathrm{mg} / \mathrm{ml}$ and $6.25 \mathrm{mg} / \mathrm{ml}$ were prepared from reconstituted stock solution. One milliliter $(1 \mathrm{~mL})$ of each concentration was dispensed in different test tubes containing $1 \mathrm{~mL}$ of sterile Mueller Hinton broth. Then 1 $\mathrm{ml}$ of an 18 hours old culture of each bacterial isolate adjusted at $0.5 \mathrm{McFarland}$ standard was dispensed into each tube and thoroughly mixed. Control tubes containing $1 \mathrm{~mL}$ of Mueller Hinton broth and $1 \mathrm{~mL}$ of Sterile distilled water without extract was employed as negative control in different tubes. The tubes were incubated at $37^{\circ} \mathrm{C}$ for 24 hours and observed for growth in form of turbidity. The MIC was the lowest concentration of extract with no visible bacterial growth or turbidity (CLSI, 2014).

\subsection{Determination of Minimum Bactericidal Concentration $(M B C)$ :}

The test tube containing the lowest dilution and with no detectable growth by visual inspection was considered the Minimum Inhibitory Concentration. A $0.1 \mathrm{ml}$ of bacterial suspension from the MIC tubes that did not show any growth was streaked on solidified Mueller Hinton agar plates and incubated at $37{ }^{\circ} \mathrm{C}$ for 24 hours. After incubation, the concentration at which no visible growth was seen was recorded as the Minimum Bactericidal Concentration (MBC) (Abegunde et al., 2018).

\subsection{Phytochemical Screening}

Qualitative phytochemical screening of the crude extracts was carried out to detect the presence of some secondary metabolites using standard laboratory techniques. Alkaloids, glycosides, saponins, steroids and terpenoids were identified with the methods of Sofowora (1993) while the methods of Harborne (1973) was adopted to test for the presence of anthraquinones, phlobatannins, flavonoids and tannin. Quantitative phytochemical screening were carried out with the methods of Sofowora (1993).

\subsection{Statistical Analysis}

Data obtained from this study was expressed as mean \pm standard deviation and were subjected to two-way analysis of variance (ANOVA) of the treatment means, showing significant difference $(\mathrm{P} \leq 0.05)$ and were separated using Duncan's multiple range tests.

\section{RESULTS}

\subsection{Antibacterial Activities of A. indica on Bacteria Isolated from the Study Area and their Typed Strains.}

Table 1 shows the zones of inhibition of $A$. indica extracts on clinical and typed isolates. Zones of inhibition of aqueous extract of $A$. indica against the isolates ranged from $(6.83 \pm$ 
$1.34)$ to $(22.80 \pm 0.98)$ and there was no significant difference ( $\mathrm{p}>0.05$ ) between the mean values with the exception of; $E$. coli isolated from co-infection of schistosomiasis and bacteriuria, and K. pneumoniae isolated from single infection of bacteriuria. The zones of inhibition of ethanol extract of $A$. indica ranged from $(14.00 \pm 0.00)$ to $(20.00 \pm 0.00)$ and there was no significant difference $(\mathrm{p}>0.05)$ between the mean values with the exception of; $E$. coli isolated from co-infection of schistosomiasis and bacteriuria, and $K$. pneumoniae isolated from single infection of bacteriuria.

\subsection{Antibacterial Activities of $S$. guineense on Bacteria} Isolated from the Study Area and their Typed Strains.

Table 2 shows the zones of inhibition of $S$. guineense extracts on clinical and typed isolates. The zones of inhibition of aqueous extract of $S$. guineense against the isolates ranged from $(14.00 \pm 1.41)$ to $(20.67 \pm 0.72)$ and there was no significant difference $(\mathrm{p}>0.05)$ between the mean values with the exception of; $E$. coli isolated from co-infection of schistosomiasis and bacteriuria, K. pneumoniae isolated from single infection of bacteriuria. Zones of inhibition of the ethanol extract ranged from $(14.00 \pm 1.41)$ to $(20.00 \pm 0.00)$ and there was no significant difference $(\mathrm{p}>0.05)$ between the mean values with the exception of; $E$. coli isolated from coinfection of schistosomiasis and bacteriuria, and $K$. pneumoniae isolated from single infection of bacteriuria.

\subsection{Minimum Inhibitory Concentration}

Table 3 shows the minimum inhibitory concentration (MIC) of Azadirachta indica extracts on both clinical and typed isolates, while table 4 reveals that of Syzigium guineense. For all the extracts, the MIC on the bacterial isolates ranged from $6.25 \mathrm{mg} / \mathrm{mL}-12.5 \mathrm{mg} / \mathrm{mL}$, except $K$. pneumoniae isolated from single infection of bacteriuria that showed a MIC of $25 \mathrm{mg} / \mathrm{mL}$ to the aqueous extracts of both leaves.

\subsection{Minimum Bactericidal Concentration}

The minimum bactericidal concentration (MBC) of aqueous extracts of Azadirachta indica and Syzigium guineense on both clinical and typed isolates is shown in Figure 1. The $\mathrm{MBC}$ for the aqueous extracts ranged from $6.25 \mathrm{mg} / \mathrm{mL}-25$ $\mathrm{mg} / \mathrm{mL}$ with the following few exceptions; $E$. coli isolated from co-infection of schistosomiasis and bacteriuria had a $\mathrm{MBC}$ of $50 \mathrm{mg} / \mathrm{mL}$ to aqueous extract of $A$. indica. Likewise, $K$. pneumoniae isolated from single infection of bacteriuria had a MBC of $50 \mathrm{mg} / \mathrm{mL}$ to aqueous extracts of both plants.

The minimum bactericidal concentration (MBC) of the ethanol extracts is shown in Figure 2. The MBC for the aqueous extracts ranged from $6.25 \mathrm{mg} / \mathrm{mL}-12.5 \mathrm{mg} / \mathrm{mL}$ with the following few exceptions; E. coli isolated from coinfection of schistosomiasis and bacteriuria, Proteus vulgaris ATCC 29905 and Enterobacter aerogenes ATCC 29905 had minimum bactericidal concentrations of $25 \mathrm{mg} / \mathrm{mL}$ to aqueous extract of $A$. indica.

3.5 Percentage Yield of Aqueous and Ethanol Extracts of A. indica and $S$. guineense Leaves
Table 5 shows the percentage yield of aqueous and ethanol extracts of A. indica and S. guineense leaves after extraction. Aqueous extracts of both $A$. indica and $S$. guineense leaves had a higher percentage yield ( $7.6 \%$ and $12 \%$ respectively), compared to the ethanol extracts (6\% and $8 \%$ respectively).

3.6 Qualitative Phytochemical Constituents of A. indica and S. guineese Crude Leave Extracts

Table 6 shows the qualitative phytochemical constituents of aqueous and ethanol extracts of $A$. indica and $S$. guineese leaves. Saponin, tannin, flavonoid, terpenoid and glycoside were present in the aqueous and ethanol extracts of both plants. Alkaloid and phlobatannin were absent in the extracts of both leaves. Steroid was found in the aqueous extract of both plants but absent in the ethanol extracts of both plants.

\subsection{Quantitative Phytochemical Constituents of A. indica and} S. guineese Crude Leave Extracts

Table 7 shows the quantity of phytochemicals present in the aqueous and ethanol extracts of $A$. indica and $S$. guineese leaves. Terpenoid $(25.15 \pm 0.04)$ was the highest phytochemical present in the aqueous extract of $A$. indica followed by cardiac glycoside $(14.74 \pm 0.07)$, while flavonoid $(0.42 \pm 0.02)$ was the lowest phytochemical contained in the aqueous extract. In the ethanol extract of $A$. indica, Saponin $(220.82 \pm 0.64)$ was the highest phytochemical, followed by terpenoid $(50.82 \pm 0.04)$, while flavonoid $(0.74 \pm 0.02)$ was the least phytochemical present in the ethanol extract of $A$. indica. Saponin $(72.09 \pm 1.67)$ was the highest phytochemical in the aqueous extract of $S$. guineense followed by cardiac glycoside $(17.17 \pm 0.04)$, while flavonoid $(1.52 \pm 0.11)$ was the lowest phytochemical contained in the aqueous extract.

\section{Tables and Figures}

Table 1: Zones of Inhibition (mm) of Azadirachta indica Extracts on Clinical and Typed Isolates.

\begin{tabular}{|c|c|c|}
\hline Isolates & Aqueous & Ethanol \\
\hline Staphylococcus aureus (+) & $22.80 \pm 0.98^{\mathrm{a}}$ & $14.00 \pm 0.00^{\mathrm{a}}$ \\
\hline Staphylococcus aureus (-) & $17.33 \pm 0.27^{\mathrm{a}}$ & $15.00 \pm 0.00^{\mathrm{a}}$ \\
\hline $\begin{array}{c}\text { Staphylococcus aureus } \\
\text { NCTC 6571 }\end{array}$ & $16.83 \pm 0.14^{\mathrm{b}}$ & $13.06 \pm 0.05^{\mathrm{b}}$ \\
\hline Escherichia coli (+) & $6.83 \pm 1.34^{\mathrm{c}}$ & $10.33 \pm 0.81^{\mathrm{c}}$ \\
\hline Escherichia coli (-) & $18.66 \pm 0.76^{\mathrm{a}}$ & $14.00 \pm 1.70^{\mathrm{a}}$ \\
\hline $\begin{array}{c}\text { Escherichia coli ATCC } \\
\text { 25922 }\end{array}$ & $16.90 \pm 0.92^{\mathrm{a}}$ & $16.00 \pm 0.00^{\mathrm{a}}$ \\
\hline Klebsiella pneumoniae (+) & $19.50 \pm 1.03^{\mathrm{a}}$ & $17.00 \pm 1.25^{\mathrm{a}}$ \\
\hline Klebsiella pneumoniae (-) & $7.53 \pm 0.03^{\mathrm{c}}$ & $15.33 \pm 0.54^{\mathrm{c}}$ \\
\hline $\begin{array}{c}\text { Klebsiella pneumoniae } \\
\text { ATCC 13885 }\end{array}$ & $15.17 \pm 0.14^{\mathrm{a}}$ & $17.83 \pm 0.49^{\mathrm{a}}$ \\
\hline Proteus vulgaris (+) & $17.33 \pm 0.27^{\mathrm{a}}$ & $17.00 \pm 0.00^{\mathrm{a}}$ \\
\hline Proteus vulgaris (-) & $15.00 \pm 0.47^{\mathrm{a}}$ & $20.87 \pm 1.35^{\mathrm{a}}$ \\
\hline $\begin{array}{c}\text { Proteus vulgaris ATCC } \\
\text { 29905 }\end{array}$ & $18.67 \pm 0.27^{\mathrm{a}}$ & $19.00 \pm 0.47^{\mathrm{a}}$ \\
\hline
\end{tabular}


International Journal of Research and Scientific Innovation (IJRSI) |Volume VIII, Issue XII, December 2021|ISSN 2321-2705

\begin{tabular}{|c|c|c|}
\hline Enterobacter aerogenes (+) & $14.67 \pm 1.91^{\mathrm{b}}$ & $16.00 \pm 0.00^{\mathrm{b}}$ \\
\hline Enterobacter aerogenes (-) & $16.00 \pm 0.94^{\mathrm{b}}$ & $17.50 \pm 0.71^{\mathrm{b}}$ \\
\hline $\begin{array}{c}\text { Enterobacter aerogenes } \\
\text { ATCC 29905 }\end{array}$ & $14.00 \pm 0.47^{\mathrm{b}}$ & $14.00 \pm 0.47^{\mathrm{b}}$ \\
\hline Salmonella enterica. (+) & $18.00 \pm 0.47^{\mathrm{a}}$ & $18.00 \pm 0.47^{\mathrm{a}}$ \\
\hline Salmonella enterica (-) & $15.50 \pm 0.24^{\mathrm{b}}$ & $10.00 \pm 0.00^{\mathrm{b}}$ \\
\hline $\begin{array}{c}\text { Salmonella typhii ATCC } \\
14028\end{array}$ & $17.00 \pm 0.00^{\mathrm{b}}$ & $17.00 \pm 0.00^{\mathrm{b}}$ \\
\hline Yersinia enterocolitica (+) & $17.00 \pm 0.00^{\mathrm{b}}$ & $14.00 \pm 1.41^{\mathrm{b}}$ \\
\hline Yersinia enterocolitica (-) & $20.00 \pm 0.00^{\mathrm{a}}$ & $20.00 \pm 0.00^{\mathrm{a}}$ \\
\hline
\end{tabular}

Data are represented as mean \pm SE (standard error). Each value is a mean of three (3) replicates Values with the same letters down the same column are not significantly different at $\mathrm{p}$-value $\leq 0.05$ (ANOVA and DMRT).

KEY: (+): Bacteria isolated from co-infection of schistosomiasis and bacteriuria;

$(-)$ : $\quad$ Bacteria isolated from single infection of bacteriuria

TABLE 2: Zones of Inhibition (mm) of Syzigium guineense Extracts on Clinical and Typed Isolates.

\begin{tabular}{|c|c|c|}
\hline Isolates & Aqueous & Ethanol \\
\hline $\begin{array}{l}\text { Staphylococcus } \\
\text { aureus (+) }\end{array}$ & $20.00 \pm 0.00^{\mathrm{a}}$ & $17.93 \pm 0.05^{\mathrm{a}}$ \\
\hline $\begin{array}{l}\text { Staphylococcus } \\
\text { aureus s (-) }\end{array}$ & $17.66 \pm 0.27^{\mathrm{a}}$ & $16.96 \pm 0.03^{\mathrm{a}}$ \\
\hline \multirow{2}{*}{$\begin{array}{c}\text { Staphylococcus } \\
\text { aureus NCTC } 6571\end{array}$} & $17.33 \pm 0.27^{\mathrm{b}}$ & $17.00 \pm 0.00^{\mathrm{b}}$ \\
\hline & & \\
\hline Escherichia coli $(+)$ & $10.56 \pm 0.28^{c}$ & $16.66 \pm 0.49^{\circ}$ \\
\hline Escherichia coli (-) & $20.67 \pm 0.72^{\mathrm{a}}$ & $17.17 \pm 2.00^{\mathrm{a}}$ \\
\hline $\begin{array}{l}\text { Escherichia coli } \\
\text { ATCC } 25922 \\
\end{array}$ & $17.33 \pm 1.44^{\mathrm{a}}$ & $18.97 \pm 0.50^{\mathrm{a}}$ \\
\hline $\begin{array}{c}\text { Klebsiella } \\
\text { pneumoniae (+) }\end{array}$ & $17.50 \pm 0.24^{\mathrm{a}}$ & $15.33 \pm 0.72^{\mathrm{a}}$ \\
\hline $\begin{array}{c}\text { Klebsiella } \\
\text { pneumoniae (-) }\end{array}$ & $10.17 \pm 1.57^{\mathrm{c}}$ & $15.50 \pm 1.03^{\circ}$ \\
\hline \multirow{2}{*}{$\begin{array}{c}\text { Klebsiella } \\
\text { pneumoniae ATCC } \\
13885 \\
\end{array}$} & $19.17 \pm 1.52^{\mathrm{a}}$ & $20.00 \pm 0.00^{\mathrm{a}}$ \\
\hline & & \\
\hline Proteus vulgaris $(+)$ & $19.33 \pm 0.27^{\mathrm{a}}$ & $20.00 \pm 0.00^{\mathrm{a}}$ \\
\hline Proteus vulgaris (-) & $15.33 \pm 0.98^{\mathrm{a}}$ & $17.20 \pm 0.16^{\mathrm{a}}$ \\
\hline $\begin{array}{l}\text { Proteus vulgaris } \\
\text { ATCC } 29905\end{array}$ & $16.33 \pm 1.36^{\mathrm{a}}$ & $16.83 \pm 0.14^{\mathrm{a}}$ \\
\hline $\begin{array}{c}\text { Enterobacter } \\
\text { aerogenes }(+)\end{array}$ & $16.67 \pm 0.98^{b}$ & $14.50 \pm 0.24^{\mathrm{b}}$ \\
\hline $\begin{array}{l}\text { Enterobacter } \\
\text { aerogenes }(-)\end{array}$ & $15.67 \pm 1.91^{\mathrm{b}}$ & $15.67 \pm 1.66^{\mathrm{b}}$ \\
\hline \multirow{2}{*}{$\begin{array}{c}\text { Enterobacter } \\
\text { aerogenes ATCC } \\
29905\end{array}$} & $15.50 \pm 0.24^{\mathrm{b}}$ & $18.00 \pm 0.47^{\mathrm{b}}$ \\
\hline & & \\
\hline $\begin{array}{c}\text { Salmonella enterica } \\
(+)\end{array}$ & $19.50 \pm 0.24^{\mathrm{a}}$ & $18.00 \pm 0.82^{\mathrm{a}}$ \\
\hline $\begin{array}{c}\text { Salmonella enterica (- } \\
\text { ) }\end{array}$ & $15.50 \pm 0.24^{\mathrm{b}}$ & $18.33 \pm 0.54^{\mathrm{b}}$ \\
\hline \multirow{2}{*}{$\begin{array}{l}\text { Salmonella typhii } \\
\text { ATCC } 14028\end{array}$} & $15.00 \pm 0.00^{\mathrm{b}}$ & $16.00 \pm 0.47^{\mathrm{b}}$ \\
\hline & & \\
\hline
\end{tabular}

\begin{tabular}{|c|c|c|}
\hline $\begin{array}{c}\text { Yersinia enterocolitica } \\
(+)\end{array}$ & $14.00 \pm 1.41^{\mathrm{b}}$ & $14.00 \pm 1.41^{\mathrm{b}}$ \\
\hline $\begin{array}{c}\text { Yersinia enterocolitica } \\
(-)\end{array}$ & $20.00 \pm 0.00^{\mathrm{a}}$ & $20.00 \pm 0.00^{\mathrm{a}}$ \\
\hline
\end{tabular}

Data are represented as mean $\pm \mathrm{SE}$ (standard error).

Each value is a mean of three (3) replicates

Values with the same letters down the same column are not significantly different at $p$-value $\leq 0.05$ (ANOVA and DMRT)

KEY: (+): Bacteria isolated from co-infection of schistosomiasis and bacteriuria;

$(-)$ : $\quad$ Bacteria isolated from single infection of bacteriuria

Table 3: Minimum Inhibitory Concentration of Azadirachta indica Extracts on Clinical and Typed Isolates.

\begin{tabular}{|c|c|c|}
\hline Isolates & $\begin{array}{l}\text { Aqueous } \\
(\mathrm{mg} / \mathrm{mL})\end{array}$ & Ethanol $(\mathrm{mg} / \mathrm{mL})$ \\
\hline Staphylococcus aureus (+) & 6.25 & 12.5 \\
\hline Staphylococcus aureus (-) & 6.25 & 12.5 \\
\hline \multirow{2}{*}{$\begin{array}{l}\text { Staphylococcus aureus } \\
\text { NCTC } 6571\end{array}$} & \multirow{2}{*}{12.5} & 12.5 \\
\hline & & \\
\hline Escherichia coli $(+)$ & 25 & 12.5 \\
\hline Escherichia coli (-) & 6.25 & 6.25 \\
\hline $\begin{array}{c}\text { Escherichia coli ATCC } \\
25922 \\
\end{array}$ & 12.5 & 6.25 \\
\hline Klebsiella pneumoniae (+) & 6.25 & 6.25 \\
\hline Klebsiella pneumoniae (-) & 25 & 6.25 \\
\hline \multirow{2}{*}{$\begin{array}{c}\text { Klebsiella pneumoniae } \\
\text { ATCC } 13885\end{array}$} & \multirow{2}{*}{6.25} & 6.25 \\
\hline & & \\
\hline Proteus vulgaris (+) & 6.25 & 6.25 \\
\hline Proteus vulgaris (-) & 12.5 & 6.25 \\
\hline $\begin{array}{c}\text { Proteus vulgaris ATCC } \\
29905\end{array}$ & 12.5 & 12.5 \\
\hline Enterobacter aerogenes $(+)$ & 6.25 & 6.25 \\
\hline Enterobacter aerogenes (-) & 6.25 & 6.25 \\
\hline \multirow{2}{*}{$\begin{array}{l}\text { Enterobacter aerogenes } \\
\text { ATCC } 29905\end{array}$} & \multirow{2}{*}{12.5} & 12.5 \\
\hline & & \\
\hline Salmonella enterica $(+)$ & 6.25 & 6.25 \\
\hline Salmonella enterica (-) & 6.25 & 12.5 \\
\hline \multirow{2}{*}{$\begin{array}{l}\text { Salmonella typhii ATCC } \\
14028\end{array}$} & \multirow{2}{*}{6.25} & 6.25 \\
\hline & & \\
\hline Yersinia enterocolitica $(+)$ & 6.25 & 12.5 \\
\hline Yersinia enterocolitica (-) & 6.25 & 6.25 \\
\hline
\end{tabular}

KEY:(+):Bacteria isolated from co-infection of schistosomiasis and bacteriuria

(-): Bacteria isolated from single infection of bacteriuria

Table 4: Minimum Inhibitory Concentration of Syzigium guineense Extracts on Clinical and Typed Isolates.

\begin{tabular}{|c|c|c|}
\hline Isolates & $\begin{array}{c}\text { Aqueous Extract } \\
(\mathrm{mg} / \mathrm{mL})\end{array}$ & $\begin{array}{c}\text { Ethanol Extract } \\
(\mathrm{mg} / \mathrm{mL})\end{array}$ \\
\hline Staphylococcus aureus (+) & 6.25 & 6.25 \\
\hline Staphylococcus aureus (-) & 6.25 & 12.5 \\
\hline Staphylococcus aureus & 6.25 & 6.25 \\
\hline
\end{tabular}


International Journal of Research and Scientific Innovation (IJRSI) | Volume VIII, Issue XII, December 2021||ISSN 2321-2705

\begin{tabular}{|c|c|c|}
\hline NCTC 6571 & & \\
\hline Escherichia coli (+) & 12.5 & 12.5 \\
\hline Escherichia coli (-) & 6.25 & 6.25 \\
\hline $\begin{array}{c}\text { Escherichia coli ATCC } \\
\text { 25922 }\end{array}$ & 12.5 & 6.25 \\
\hline Klebsiella pneumoniae (+) & 6.25 & 6.25 \\
\hline Klebsiella pneumoniae (-) & 25 & 6.25 \\
\hline $\begin{array}{c}\text { Klebsiella pneumoniae } \\
\text { ATCC 13885 }\end{array}$ & 6.25 & 6.25 \\
\cline { 2 - 3 } & & 6.25 \\
\hline Proteus vulgaris (+) & 6.25 & 6.25 \\
\hline Proteus vulgaris (-) & 12.5 & 6.25 \\
\hline Proteus vulgaris ATCC & 6.25 & \\
\hline
\end{tabular}

\begin{tabular}{|c|c|c|}
\hline Enterobacter aerogenes (+) & 6.25 & 6.25 \\
\hline Enterobacter aerogenes (-) & 6.25 & 6.25 \\
\hline $\begin{array}{c}\text { Enterobacter aerogenes } \\
\text { ATCC 29905 }\end{array}$ & 12.5 & 6.25 \\
\cline { 2 - 3 } & & \\
\hline Salmonella enterica (+) & 6.25 & 6.25 \\
\hline Salmonella enterica (-) & 6.25 & 6.25 \\
\hline $\begin{array}{c}\text { Salmonella typhii ATCC } \\
\text { 14028 }\end{array}$ & 12.5 & 12.5 \\
\cline { 2 - 3 } & & \\
\hline Yersinia enterocolitica (+) & 12.5 & 6.25 \\
\hline Yersinia enterocolitica (-) & 6.25 & 6.25 \\
\hline
\end{tabular}

KEY: $\quad(+)$ : $\quad$ Bacteria isolated from co-infection of schistosomiasis and bacteriuria

$(-) \quad \quad$ Bacteria isolated from single infection of bacteriuria

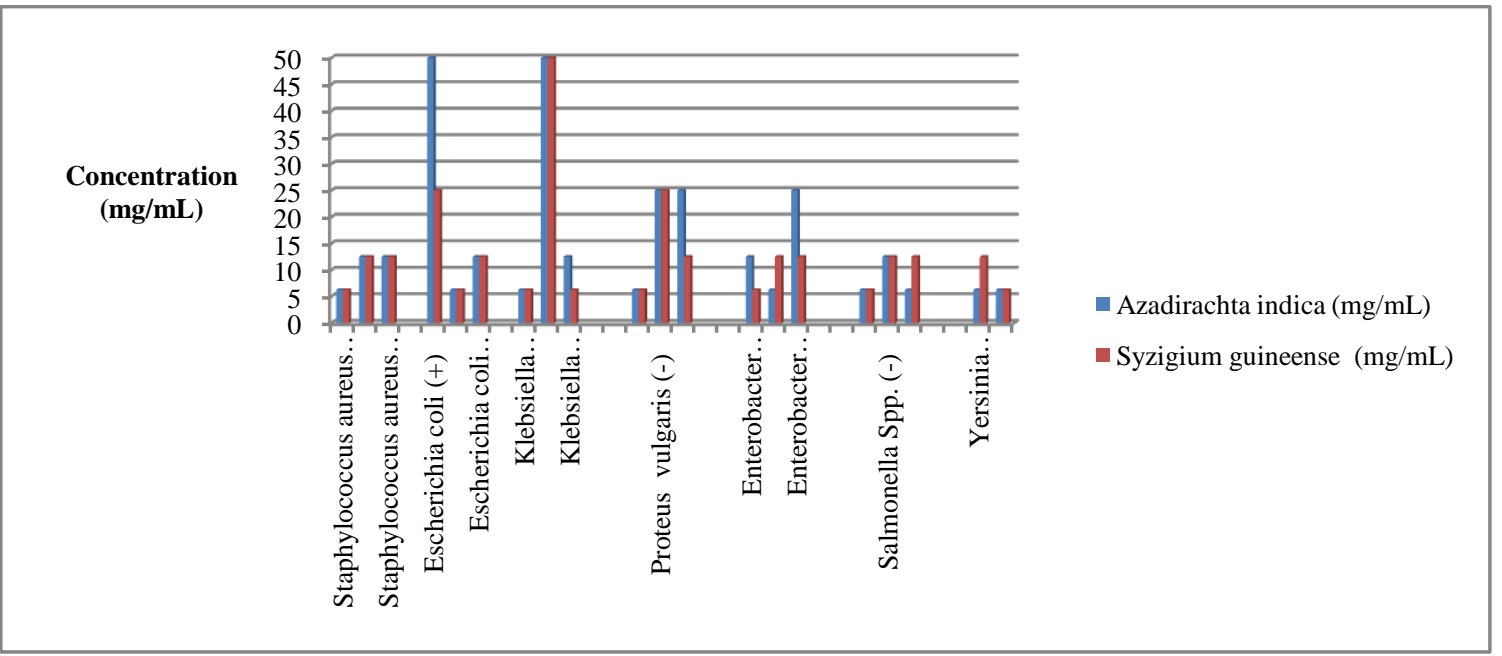

Figure 1: Minimum Bactericidal Concentration of Aqueous Extracts of Azadirachta indica and Syzigium guineense on Clinical and Typed Isolates

KEY: $\quad(+)$ : $\quad$ Bacteria isolated from co-infection of schistosomiasis and bacteriuria

$(-)$ : $\quad$ Bacteria isolated from single infection of bacteriuria

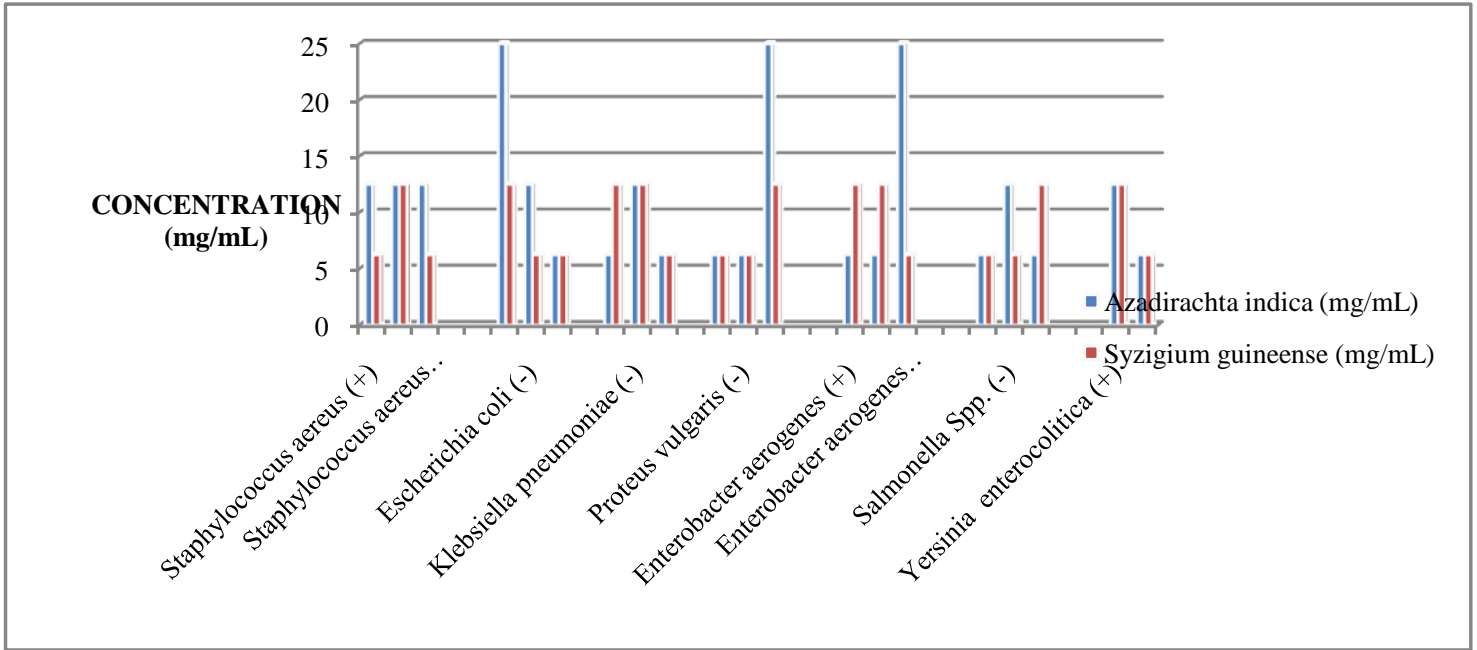

Figure 2: Minimum Bactericidal Concentration of Ethanol Extracts of Azadirachta indica and Syzigium guineense on Clinical and Typed Isolates

KEY: $\quad(+): \quad$ Bacteria isolated from co-infection of schistosomiasis and bacteriuria

$(-) \quad \quad$ Bacteria isolated from single infection of bacteriuria. 
Table 5: Percentage Yield of Aqueous and Ethanol Extracts of A. indica and S. guineense Leaves

\begin{tabular}{|c|c|c|c|}
\hline Extract & $\begin{array}{c}\text { Original } \\
\text { Weight } \\
(\mathrm{g})\end{array}$ & $\begin{array}{c}\text { Extract Weight } \\
(\mathrm{g})\end{array}$ & $\begin{array}{c}\text { Percentage } \\
\text { Recovery }(\%)\end{array}$ \\
\hline $\begin{array}{c}\text { Azadirachta indica } \\
\text { (Aqueous Extract) }\end{array}$ & 100 & 7.6 & 7.6 \\
\hline $\begin{array}{c}\text { Syzigium guineense } \\
\text { (Aqueous Extract) }\end{array}$ & 100 & 12 & 12 \\
\hline $\begin{array}{c}\text { Azadirachta indica } \\
\text { (Ethanol Extract) }\end{array}$ & 100 & 6 & 8 \\
\hline $\begin{array}{c}\text { Syzigium guineense } \\
\text { (Ethanol Extract) }\end{array}$ & 100 & 8 & 6 \\
\hline
\end{tabular}

Table 6: Qualitative Phytochemical Constituent of Aqueous and Ethanol 'Extracts of A. indica and S. guineese Leaves

\begin{tabular}{|c|c|c|c|c|}
\hline $\begin{array}{c}\text { Phytochemical } \\
\mathrm{s}\end{array}$ & \multicolumn{2}{|c|}{ AQUEOUS } & \multicolumn{2}{c|}{ ETHANOL } \\
\hline & $\begin{array}{c}\text { Azadirach } \\
\text { ta indica }\end{array}$ & $\begin{array}{c}\text { Syzigium } \\
\text { guineense }\end{array}$ & $\begin{array}{c}\text { Azadirach } \\
\text { ta } \text { indica }\end{array}$ & $\begin{array}{c}\text { Syzigium } \\
\text { guineense }\end{array}$ \\
\hline Saponin & + & + & + & + \\
\hline Tannin & + & + & + & + \\
\hline Phlobatannin & - & - & - & - \\
\hline Flavonoid & + & + & + & + \\
\hline Steroid & + & + & - & - \\
\hline Terpenoid & + & + & + & + \\
\hline $\begin{array}{c}\text { Alkaloid } \\
\text { Keller Kiliani } \\
\text { Test }\end{array}$ & - & - & - & - \\
\hline $\begin{array}{c}\text { Salkwoski } \\
\text { Test }\end{array}$ & + & + & + & + \\
\hline $\begin{array}{c}\text { Liberman } \\
\text { Test }\end{array}$ & + & + & + & + \\
\hline
\end{tabular}

Table 7: Quantitative Phytochemical Constituents of Aqueous and Ethanol Extracts of A. indica and S. guineese Leaves

\begin{tabular}{|c|c|c|c|c|}
\hline \multirow[t]{2}{*}{ Phytochemicals } & \multicolumn{2}{|c|}{ Azadirachta indica } & \multicolumn{2}{|c|}{ Syzigium guineense } \\
\hline & Aqueous & Ethanol & Aqueous & Ethanol \\
\hline Saponin $(\mathrm{mg} / \mathrm{g})$ & $7.18 \pm 0.30^{\mathrm{a}}$ & $220.82 \pm 0.64^{c}$ & $72.09 \pm 1.67^{\mathrm{b}}$ & $4.91 \pm 0.08^{\mathrm{d}}$ \\
\hline Tannin (mg/g) & $3.70 \pm 0.01^{\mathrm{a}}$ & $5.28 \pm 1.69^{\mathrm{c}}$ & $5.16 \pm 0.06^{\mathrm{b}}$ & $8.14 \pm 0.14^{\mathrm{d}}$ \\
\hline Flavonoid (mg/g) & $0.42 \pm 0.02^{\mathrm{a}}$ & $0.74 \pm 0.02^{\mathrm{c}}$ & $1.52 \pm 0.11^{\mathrm{b}}$ & $3.60 \pm 0.03^{\mathrm{d}}$ \\
\hline Steroid (mg/g) & $9.32 \pm 0.08^{\mathrm{a}}$ & $0.00 \pm 0.00$ & $2.75 \pm 0.02^{b}$ & $0.00 \pm 0.00$ \\
\hline Terpenoid (mg/g) & $25.15 \pm 0.04^{\mathrm{a}}$ & $50.82 \pm 0.04^{\mathrm{c}}$ & $37.48 \pm 0.07^{\mathrm{b}}$ & $51.16 \pm 0.03^{\mathrm{d}}$ \\
\hline Cardiac glycoside (mg/g) & $14.74 \pm 0.07^{\mathrm{a}}$ & $21.36 \pm 0.09^{\mathrm{c}}$ & $17.17 \pm 0.04^{\mathrm{b}}$ & $18.19 \pm 0.07^{\mathrm{d}}$ \\
\hline
\end{tabular}

Data are represented as mean $\pm \mathrm{SE}$ (standard error).

Values with the same superscript letters along the same row are not significantly different $(\mathrm{p} \leq 0.05)$

\section{DISCUSSION}

The observed antibacterial activities of A. indica and $S$. guineense extracts against bacterial isolates in this study corresponds with the findings of Itelima et al. (2016), and Okhale et al. (2018) and supports its use in traditional medicine. This may be due to the abundance of saponin, terpenoid and cardiac glycosides in the plant extracts. Terpenoids are lipophilic compounds that act by disrupting bacterial cell membrane while saponins are said to be detergent-like substances that disrupt the permeability of the bacterial outer membrane (Jasmine et al., 2011; Arabski et al., 2012). Ethanol extracts of both plants were more effective against all the test isolates than the aqueous extracts which agrees with the findings of Mophatra et al. (2014), and Chibuzo (2019). This could be because ethanol solvent can extract both polar and non-polar bioactive constituents, whereas, non-polar compounds do not readily dissolve in aqueous solution.

The higher extraction yield of aqueous extracts of both plants than ethanol extract agrees with the study of El-Mahmood (2009), who reported higher extract yield in cold water compared to other solvent used in extraction of Euphorbia hirta plant, and that of Mohd et al. (2012), who reported highest yield in aqueous compared to the other solvents used in the extraction of Orthosiphon stamineus. Factors like the age of the plant and the polarity of the solvent used often affect the yield of extracts (El-Mahmood, 2009). The higher extraction yield of aqueous extract in this study could be due to the higher polarity of water compared to other solvents. This finding therefore supports the use of water as solvent of choice for plant extraction in traditional practice.

The presence of saponin, tannin, flavonoid, terpenoid, and cardiac glycosides in the aqueous and ethanol extracts of $A$. inidca and $S$. guineense supports the findings of Itelima et al. (2016), and Abera et al. (2018). While the absence of alkaloid in the extracts of $A$. indica is in agreement with the observations of Mophatra et al (2014), and Raissa et al. (2019), who recorded the absence of alkaloid in the aqueous and ethanol extract of $A$. indica. Similarly, the presence of steroid in the aqueous extracts of A. indica and its absence in ethanol extract is in accordance with the report of Mophatra $e t$ al. (2014). Saponin and terpenoid were the most abundant 
bioactive compound in extract of A. indica which is in agreement with Owoyale et al. (2019). Similar to the report of Abera et al. (2018), terpenoid and cardiac glycoside were the most abundant bioactive compounds in $S$. guineense extract.

Based on the result of the antibiogram, bacteria associated with urinary schistosomiasis showed higher resistance to conventional antibiotics than non-associated bacteria (Dada and Benita 2021), which corroborates the studies of Barnhill et al. (2011), and could due to the protection conferred by Schistosoma haematobium to co-contaminant bacteria when they attach themselves to the tegument of the adult schistosomes (Hsiao et al., 2016). This probably explains why unlike conventional antibiotics, extracts of $A$. indica and $S$. guineense demonstrated remarkable antibacterial activities against bacteria implicated in single infection of bacteriuria as well as bacteria associated with urinary schistosomiasis in this study.

\section{CONCLUSION}

Findings from the study revealed that extracts of $A$. indica and $S$. guineense demonstrated remarkable antibacterial activities against bacteria associated with urinary schistosomiasis and bacteria isolated from single infection of bacteriuria, the extracts also compared favourably with standard antibiotics, which validate their candidacy as herbal medicines. In addition, ethanol extracts of both $A$. indica and $S$. guineense possessed greater antibacterial activities compared to the aqueous extracts. Thus, ethanol extracts of $A$. indica and $S$. guineense could be considered as alternative medicine to address the growing issue of antimicrobial resistance, high costs of antibiotics and the side effects of antibiotics.

\section{REFERENCES}

[1] Abegunde, M. T., Akinpelu, D. A., Omololu-Aso, J., Otusanya, O. O. and Akinlolu, J. T. (2018). Determination of Antimicrobial, Antioxidant and Phytochemical Properties of Cocos nucifera linn Endocarp Extract on Bacteria Associated with Human Infection. Journal of Pharmaceutical Microbiology. 4(1): 4.

[2] Abera, B., Adane, L. and Mamo, F. (2018). Phytochemical Investigation the Root Extract of Syzygium guineense and Isolation of 2,3,23-trihydroxy methyl oleanate. Journal of Pharmacognosy and Phytochemistry. 7(2): 3104-3111.

[3] Arabski, M., Wegierek-Cuik, A., Czerwonka, G., Lankoff, A. and Kaca, W. (2012). Effects of Saponins against Clinical E. coli strains and Eukaryotic Cell Line. Journal of Biomedicine and Biotechnology: 6(12): 334-340.

[4] Asoso, O. S., Akharaiyi, F. C. and Animba, L. S. (2016). Antibacterial Activities of Plantain (Musa paradisiaca) Peel and Fruit. Scholars Research Library; Der Pharmacia Lettre. 8(5): 511.

[5] Barnhill, A. E., Novozhilova, E., Day, T.A. and Carlson, S. A. (2011).Schistosoma-associated Salmonella Resist Antibiotics via Specific Fimbrial Attachments to the Flatworm. Parasites and Vectors.4:123-130.

[6] Chibuzo, U. C. (2019). Antimicrobial Activity of Azadirachta indica (Neem) Leaf Extract on Some Bacteria. International Journal of Current Microbiology and Applied Sciences. 8(7): 431437.

[7] Clinical and Laboratory Standards Institute (CLSI) (2014). Performance Standards for Antimicrobial Susceptibility Testing; 20th Edition (June 2010 update). Document M100-S20U. Wayne, PA: CLSI; 2010: 25 pages.

[8] Dada, E. O. and Alagha, B. A. (2021). Urinary Schistosomiasis and Asymptomatic Bacteriuria among Individuals of Ipogun, Nigeria: Detection of Predominant Microorganisms and Antibiotic Susceptibility Profile. Journal of Medical and Health Studies. 2(2): $70-80$.

[9] Daswani, P. G. (2019), Non-antibiotic potential of medicinal plants to combat urinary tract infections. Department of Medicinal Plants, the foundation for medical research, 84a, rg, Thadani Marg, Worli, Mumbai 400 018, India. Current Science. 11(7): 917.

[10] El-Mahmood A.M. (2009). Antibacterial activity of crude extracts of Euphorbia hirta against some bacteria associated with enteric infections. Journal of Medicinal Plants Research: 3(7): 498-505.

[11] Harborne, J. B. (1973). Phytochemical Methods: A Guide to Modern Techniques of Plant Analysis. $2^{\text {nd }}$ Edition. Chapman and Hall Limited, London. Page 279

[12] Hsiao, A., Toy, T., Seo, H. J. and Marks, F. (2016), Interaction between Salmonella and Schistosomiasis:A Review. Plos Pathogens. 12(12): E1005928.

[13] Itelima, J. (2016). Phytochemical Screening and Antimicrobial activity evaluation of Aqueous and Ethanolic Extracts of the Leaf of Azadirachta indica (neem) on some Microorganisms.World Journal of Microbiology. 3:038-042.

[14] Jasmine, R., Selvakumar, B. N. and Pitchai, A. D. (2011). Investigating the Mechanism of Action of Terpenoids and the Effect of Interfering Substances on an Indian Medicinal Plant Extract Demonstrating Antibacterial. International Journal of Pharmaceutical Studies and Research. 5: 1832-1837.

[15] Kidane, A., Rezene, A. G., Hannes, O. G., Michael, S., Mehreteab, S., Jyoti, J. and Andom, H. (2019). Antibacterial Activities of Selected Medicinal Plants against Multi-drug Resistant Bacteria Isolated from Urine Samples of Catheterized Patients. Clinical Microbiology. 8:328-341.

[16] Mahomoodally, M. F. (2013). Traditional Medicines in Africa: An Appraisal of Ten Potent African Medicinal Plants. Hindawi Publishing Corporation Evidence-Based Complementary and Alternative Medicine. 14: 45-61.

[17] Mohd, F. B. Razak, A., Yong, P. K., Shah, Z/ M. D., Abdullah, L. C., Yee, S. S. and Yaw, T. C. S. (2012). The Effects of Varying Solvent Polarity on Extraction Yield of Orthosiphon stamineus Leaves. Asian Network for Scientific Information. 12 (11): $1207-$ 1210.

[18] Mohaptra, A., Kanchan, P., Ranjan, M., Horta, S. M. and Prinyanka, M. (2014). Antimicrobial Activity of Neem (Azadirachta indica) Leaf Extracts. International Journal of Research in Agricultural Sciencse Volume 1, Issue 2, ISSN (Online): 2348 - 3997.

[19] Nwankwo, I. U. and Amaechi, N. (2013). Preliminary Phytochemical Screening and Antibacterial Occidentale. Journal of Research in Antimicrobials. 1(2): 69-74.

[20] Okhale, S. E., Buba, C. I., Oladosu, P., Ugbabe, G. E., Ibrahim, J. A., Egharevba, O. and Kunle, O. F. (2018). Chemical Characterization, Antioxidant and Antimicrobial Activities of the Leaf Essential Oil of Syzgium guineense (Willd.) DC. var. Guineense (Myrtaceae) from Nigeria. International Journal of Pharmacognosy and Phytochemical Research. 10(11): 41-349.

[21] Owoyale, A. D. M., Galadimma, M., Daniyan, S. Y. and Adabara, N. (2019). Quantitative Phytochemical Analysis and Antifungal Susceptibility of Azadirachta indica against Some Strains of Candida albicans. Journal of Advances in Medical and Pharmaceutical Sciences. 21(4): 1-14.

[22] Rassai, R., Safitri, A., Beltran, M. A. G., and Aulanni'am, A. (2019). Phytoconstituents Investigation on the Ethanolic Extract of Azadirachta indica var. Indonesian and Philippines. Smart Molecule of Natural Rresources. 1374 (5): 067-074. 
[23] Saheen, G., Shah, S. M. A., Akram, M. and Munir, N. (2019). Therapeutic Potential of Medicinal Plants for the Management of Urinary Tract Infection: A Systematic Review. Clinical Experimental Pharmacology and Physiology. 10: 1440-1681.
[24] Sofowora A. (1993). Screening plants for bioactive agents. In: Medicinal Plants and Traditional Medicinal in Africa. 2nd Edition. Spectrum Books Limited Ibadan. Page: 134-156.

[25] Tripathi, P. and Singh, A. (2020). Acacia nilotica, albizia saman, azadirachta indica: Ethanobotany and Medicinal uses. Modern Research in Botany. 1:1-6. 